\title{
Assessment of carbon stock potential of parkland agroforestry practice: the case of Minjar Shenkora; North Shewa, Ethiopia
}

\author{
Reta Eshetu Tsedeke ${ }^{* *} \mathbb{D}$, Seid Muhie Dawud ${ }^{2}$ and Solomon Mulu Tafere ${ }^{2}$
}

\begin{abstract}
Background: The anthropogenic global climate change has negative impacts on various sectors and communities who particularly rely on rain-fed agriculture. Parkland agroforestry practice can contribute to mitigate and adapt to the forthcoming climate change through carbon sequestration. However, empirical studies on carbon stocks potential of parklands agroforestry practices.

Methodology: By using two-stage stratified random sampling technique, 4 kebeles from two agro ecology were selected and 8 farms/plots/ of $40 \mathrm{~m} * 40 \mathrm{~m}$ sample size were selected from each kebele for the vegetation inventory. Tree species-specific allometric equations were used to determine carbon stock potential of parkland agroforestry practice.

Results: The result reveal that, AGC, BGC, SOC and Total Carbon have significant variation $(p<0.05)$ across kebeles. The mean total carbon stock of Bolo Giorgis, Bolo Slase, Agirat and Korma Agere is $48.87 \mathrm{Mg} \mathrm{C} \mathrm{ha}^{-1}, 58.21 \mathrm{MgC} \mathrm{ha}^{-1}$, $57.81 \mathrm{Mg} \mathrm{Cha}{ }^{-1}$ and $73.71 \mathrm{Mg} \mathrm{Cha}^{-1}$; respectively. On average, carbon stock of parklands practice in Minjar shenkora was $59.65 \mathrm{Mg} \mathrm{Cha}^{-1}$.

Conclusions: The parkland agroforestry practice has a large potential to deliver regulating ecosystem services like opportunities to mitigate the impending climate-changing through carbon sequestration and increasing the resilience of the agricultural system at Minjar shenkora woreda. To enhance the multiple ecosystem services of the parkland agroforestry practices in sustainable way: local by-laws should be strengthened to avoid illegal tree cutting and free grazing.
\end{abstract}

Keywords: Soil organic carbon, Above-ground biomass carbon, Below-ground biomass carbon

\section{Background}

The anthropogenic global climate change has negative impacts on various sectors and communities who particularly rely on rain-fed agriculture. The most prominent factor driving this climate change is increased atmospheric concentrations of greenhouse gases (GHGs) (WMO 2007). As it is widely documented, the current global climate change is caused by the increase in the

\footnotetext{
*Correspondence: retaeshetu@yahoo.com

1 Debre Birhan Agriculture Research Center, Amhara Region Agriculture

Research Institute, P.O. Box 112, Debre Berhan, Ethiopia

Full list of author information is available at the end of the article
}

average temperature of the Earth's near-surface air and oceans in recent decades and its projected continuation (Asako 2007).

A key mitigation strategy is to reduce the atmospheric concentrations of GHGs, particularly carbon dioxide $\left(\mathrm{CO}_{2}\right)$, through the process of carbon sequestration (Nair,2011), besides reducing emission at source. Carbon sequestration can be done in terrestrial ecosystems such as in forests and agroforests, woodland scrubland and etc. Agroforestry is the practice of growing trees and crops or pasture in interacting combinations (Nair et al. 2010). It is a tree-based farming system that has been practiced for a long period of time 
in many countries including Ethiopia. During the past four decades, agroforestry has been known as an integrated approach to sustainable land use because of its production and environmental benefits. Its recent recognition as global climate change mitigation strategy under the Kyoto Protocol has given it an added attention (Nair et al. 2009).

Agroforestry has various systems and practices. Among others, the practices include parklands. Parklands are generally understood as landscapes in which mature trees occur scattered in cultivated or recently fallowed fields (Abdelkadir and Bishaw 2003); or it is the coexistence of woody plants and grasses in subtropical and tropical savanna ecosystem (Bayala et al. 2006). The practice involves the growth of individual trees and shrubs in wide spaces in the farmland, while field crops are grown in the understory. Some of these trees were left when the natural forest was converted to other land uses; others regenerated after the land was cleared by farmers; and still others are deliberately retained or planted on the farmland (ICRAF. 2006) to provide multiple products and services such as soil structure improvement, moderate local climate, reduce erosion hazards and carbon sequestration.

Carbon sequestration refers to the removal of $\mathrm{C}$ from the atmosphere and deposition or storage in a reservoir such as oceans, vegetation or soil (Jose 2009). Carbon sequestration in terrestrial ecosystems such as agroforestry systems and practices involves primarily the uptake of atmospheric $\mathrm{CO}_{2}$ through photosynthesis and transfer of the fixed carbon into biomass, detritus, and soil pools for storage (Nair 2011). The pools are categorized into above-ground and below-ground biomass, litter and soils. The above-ground biomass includes the carbon stored in live stems and leaves of trees and herbaceous plants and in standing and downed dead wood, belowground biomass contains roots whereas litter/detritus and soils include the carbon stored in dead plant and animal parts, defecates, and the carbon stored in various soil horizons.

The mean carbon stock in soil and above-ground parts are estimated to hold major portions, roughly 60 and 30\%, respectively, in tree-based land-use systems (Pan et al. 2011; Jose S. 2012). The estimates of carbon stored in agroforestry systems (AFSs) range from 0.29 to $15.21 \mathrm{Mgha}^{-1} \mathrm{yr}^{-1}$ above-ground and 30 to $300 \mathrm{Mg}$ $\mathrm{C} \mathrm{ha}^{-1}$ up to $1 \mathrm{~m}$ depth in the soil. Recent studies under various AFSs in diverse ecological conditions showed that tree-based agricultural systems, compared to treeless systems, stored more carbon in deeper soil layers near the tree than away from the tree; higher soil organic carbon content was associated with higher species richness and tree density (Nair et al. 2010).
Most of the carbon in trees and shrubs are accumulated in above-ground biomass (AGB) and $50 \%$ of the total biomass is taken as carbon stock (Aklilu et al. 2015). Above-ground carbon stock is the amount of carbon that is assumed to be $50 \%$ of the total vegetation biomass (ICRAF. 2006; Lal 2005). The below-ground biomass of vegetation is considered as a fraction that takes about $25-30 \%$ of above-ground biomass depending on the nature of the plant, its root system, and ecological conditions (ICRAF. 2006; Lal 2005). Total biomass carbon is the sum of above and below ground carbon in vegetation (Kumar and Nair 2011).

Agroforestry systems improve the resilience of smallholder farmers through more efficient water utilization, improved microclimate, enhanced soil productivity and nutrient cycling, control of pests and diseases, improved farm productivity, and diversified and increased farm income while at the same time sequestering carbon (Lasco et al. 2014).

Understanding above-ground tree biomass and soil organic carbon stocks provide opportunities for better management of the carbon pools. However, more rigorous research results are required for agroforestry systems to be used in global agendas of carbon sequestration (Nair et al. 2010).

Agroforestry systems and practices contribute to combat different economic and ecological problems. Studies on agroforestry systems have so far mainly focused on their spatial design, food production, soil fertility management, and system interactions, and little attention has been given to their ecosystem services, such as biodiversity conservation and carbon sequestration (Negash 2013). In Minjar Shenkora woreda, like many parts of Ethiopia, there is a remarkable experience of traditional agroforestry practices mainly with parkland agroforestry practice on cultivated land. The carbon stock potential of parklands is different in sites due to variation in agro-climatic factors, in tree species, density and structure of tree species, management applied to parkland trees, agricultural land management (fertilization, fallowing, cropping of legumes, etc.), topographic factors (aspect, slope, and altitude), soil types, land-use history, etc. The presence of these large sources of variations and confounding factors highlighted that site-specific data is required to estimate its carbon stock potentials. On top of that, the potential of the parkland agroforestry in Minjar Shenkora for climate change mitigation was not investigated. Understanding the context-specific carbon stock of the parkland agroforestry will help land managers for better management of the carbon pools that are biomass and SOC. As a result, this study intended to carry out this study on parkland agroforestry practices at Minjar Shenkora woreda. 
The study generated and documented important information on the role of parkland agroforestry practice in Minjar Shenkora woreda to climate change mitigation through carbon sequestration. This study will contributed to knowledge to the conservation of these unique agroforestry systems and to the recognition of the ecosystems services they provide to the local communities (food production, and income, soil and water protection, maintenance of soil fertility) and beyond (carbon sequestration and climate change mitigation, and conservation of biodiversity) (Negash 2013). This study aimed at determining the carbon stock potential of parkland agroforestry practice in Minjar Shenkora woreda, North Shewa, Ethiopia. The question that addressed in this experiment are: carbon stored in the parkland agroforestry practice of the study area, carbon stored in above, below ground and soil carbon pools in the study area and select tree species that have the highest carbon stock potential in the study area.

\section{Materials and methods Site description}

The study was carried out in Minjar Shenkora Woreda, North Shewa Zone of Amhara Regional State, Ethiopia which is located at about $135 \mathrm{~km}$ south-east of Addis Ababa, at $90^{\circ} 6^{\prime}$ and $90^{\circ} 5^{\prime} \mathrm{N}$ and $39^{\circ} 46^{\prime}$ and $39^{\circ} 26^{\prime}$ East and has a total area of about $229,463 \mathrm{ha}$. The altitude of the study area ranges from 1400 to 2400 m.a.s.l. The topography of lands in the woreda is characterized by diverse geomorphological features. Data from the Woreda agricultural office indicate that plateau or flat plains features (65\%), followed by $20 \%$ of the land area is mountainous, ravines (10\%) and 5\% other topographic features (MSDARDO 2008).

According to MSDARDO, Minjar Shenkora woreda has different soil types suitable to harvest various kinds of grains. The most dominant soil type in the study area is heavy clay soils known as vertisols and reddish-brown loam known as cambisol.

The woreda falls within three major agro-climatic zones, Dega (high altitude), Weyna Dega (Mid altitude) and Kola (low altitude). The highest mean annual rainfall of the study area within the last ten years was $1028 \mathrm{~mm}$, whereas the lowest mean total was $162.8 \mathrm{~mm}$. According to North Shewa Agricultural and Rural Development Bureau, Minjar Shenkora district has annual average temperature range between $13.21^{\circ} \mathrm{C}$ and $23.02^{\circ} \mathrm{C}$.

The vegetation type is Acacia wooded grassland (Ib Friis 2010). On most of the plain areas on which crop cultivation is dominant, Faidherbia albida, A. tortilis, A. seyal, A. nilotica, Croton macrostachyus, and Ziziphus mauritiana are scattered across with the farm plots which are the main components of agroforestry type of agricultural system with agricultural crops.

Cereals and pulses are among the commonly cultivated crops in the area for the purpose of household consumption and income through the sale. These include sorghum (Sorghum bicolor), wheat (Triticum aestivum), teff (Eragrostis teff), barley (Hordeum vulgare), onion (Allium cepa), pea (Pisum sativum), Chickpea (Cicer arietinum) and Horse bean (Vicia faba). Currently, due to the introduction of rainwater harvesting technology through ponds, farmers grow vegetables in small gardens as well as in the fields.

\section{Materials}

The equipment used for fieldwork should be accurate and durable to withstand the rigors of use under adverse conditions. The type of equipment required depended on the type of measurements (Pearson et al. 2005). The following materials were used for this study to collect available data meter tape for measuring distances of sample plot, hypsometer to measure height of tree, caliper to measure tree diameter, auger to take soil sample, cloth or paper bags to collect soil sample, core sampler to take soil sample for bulk density and Global Positioning System (GPS) to collect coordinate point of study site.

\section{Sampling and data collection methods}

The Minjar Shenkora woreda is selected purposively as a study area by considering the extensive presence of parkland agroforestry practice. A preliminary reconnaissance survey had been conducted to identify the study area. Key informants i.e. development agents, elders and woreda natural resource experts were consulted to identify farmers and study site that contain parklands agroforestry practice on their lands-based accessibility, resource and time. The woreda is composed of 27 kebeles out of which parkland agroforestry practice is found in 21 kebeles. Moreover, the woreda has three agro-ecologic zones: dega with 6 kebeles; weyna dega with 11 kebeles; and kola with 10 kebeles. Based on this information from the woreda office of agriculture, two-stage stratified random sampling technique was used to select the unit of sampling for the study. In the first stage, a total of four kebeles: two kebeles (Bolo Giorgis and Bolo Slase) from weyna dega and two kebeles (Agirat and Korma Ager) from Kola agro-ecologies were selected randomly as specific study areas. In the second stage, by considering the list of farmers who owned farms with parkland agroforestry practice in the kebeles as a sampling frame, a total of 32 farm plot for the carbon stock determination, size $40 \mathrm{~m} * 40 \mathrm{~m}$ (Talemos and Sebsebe. 2017; Tadesse 2015).) were randomly selected from Bolo Giorgis, Bolo Slase, Agirat and Korma Ager. The sample size accounts about 
$7 \%$ of the household and therefore considered adequate to balance reliability and cost. There are different mechanisms to determine the number of samples: the census for small populations, imitating a sample size of similar studies, using published tables, and applying formulas to calculate sample size (Israel 1992). Among the listed methods sample size determination using similar studies was employed for the present study (Asefa and Worku 2014; Tadesse 2015).

The plot method was used that involves selecting plots of an appropriate size and number, laying them randomly in the selected strata (Tadesse 2015). Plots can be marked at four corners in conspicuously (for example, by sinking available material below the ground and navigating to plot using a GPS. The plot size chosen was large enough to encompass the diversity of tree species on the smallholdings (Negash 2013; Nair et al. 2008).

Carbon stock of woody species (dead trees, live trees), below-ground biomass (stumps plus coarse roots; $>2 \mathrm{~cm}$ diameter and fine roots) and soil organic carbon were estimated. The farmland of sample households was used as a sample plot for inventory. Accordingly, woody species inventory was carried out on the farmlands of selected households located in the kebeles. In present study, woody species data were collected from $40 \mathrm{~m} \times 40 \mathrm{~m}$ sample size quadrates (Nikiema 2005), but the quadrat size in the study of the mentioned author is $50 \mathrm{~m}^{*} 100 \mathrm{~m}$ because of low density of trees on farmland in the study area, However; in our case as the density of trees on farmland is relatively high, a sample plot of $40 \mathrm{~m}^{*} 40 \mathrm{~m}$ was considered as an optimum plot size. The collected data were the name of species, tree diameter at breast height, tree height, tree diameter at stump height, soil sample, and location of the plot using GPS. All the woody species in each sample plot $\geq 5 \mathrm{~cm}$ DBH (diameter at breast height) were measured because below these DBH there are insignificant amount of biomass (Motuma et al. 2008). At every sampling point, a number of individuals per plot, $\mathrm{DBH}$, height, and DSH of live trees were measured and recorded by using a measuring tape, caliper, and hypsometer.

At every sampling point from the selected study site, $20 \times 20 \mathrm{~m}$ subplots were taken for soil sampling from each corner and at the center of the plot. The most common depth for sampling is $30 \mathrm{~cm}$ but sometimes SOC is sampled to up to $1 \mathrm{~m}$ (David 2013). The importance of sampling beyond the surface soil cannot be overemphasized while studying tree-based systems such as agroforestry, not only because tree roots extend to deeper soil horizons, but also because of the role of subsoil in longterm stabilization of $C$. Soil sample taken in the depth of $0-20 \mathrm{~cm}$ and $21-40 \mathrm{~cm}$ by using auger and core sampler. Two sets of soil samples were taken, one set for the determination of SOC contents and fine root $(<2 \mathrm{~cm}$ diameter) biomass and others for the determination of soil bulk density. In each case, samples of the $0-20 \mathrm{~cm}$ and $21-40 \mathrm{~cm}$ layers were taken from the four corners and center of each of $20 \times 20 \mathrm{~m}$ tree inventory plot and composited by layer while following (Negash and Starr 2015). Two soil samples were taken from each sampling point after compositing the same depths together to get one representative soil sample. Four replication "eight plots for each replication " two soil depth, and hence a total of 64 soil samples were taken for soil carbon analysis.

\section{Data analysis}

The non-destructive method was used for the estimation of carbon stock. The $\mathrm{C}$ content of tree biomass had been taken to $48 \%$, the biomass weighted mean value for trees grown in agroforestry systems in Kenya (Kuyah et al. 2012a). To estimate biomass of tree species-specific allometric equation from woody biomass inventory for Ethiopia was used for almost all tree species (Appendix 2) but for Citrus sinensis general allometric equation (Kuyah et al. 2012a) was used.

$$
\mathrm{AGB}=0: 0905 * \mathrm{DBH}^{2: 4718} ; \mathrm{R}^{2}=0: 98 ; \mathrm{n}=72
$$

This equation was developed in areas having similar environmental conditions (climate and soils) with the study area. $\mathrm{CO} 2$ was calculated using this formula; the amount of carbon is multiplied by the ratio of the molecular weight of carbon dioxide to the atomic weight of carbon (44/12) (Tadesse 2015)).

Below ground biomass (BGB) (stump plus coarse roots, $>2 \mathrm{~cm}$ diameter and fine root) was estimated by using the allometric equation (Kuyah et al. 2012a);

$$
\mathrm{BGB}=0.490 \mathrm{AGB}^{0: 923} ; \mathrm{R}^{2}=0.95 ; \mathrm{n}=72
$$

The soil samples were analyzed to determine SOC, soil organic matter, $\mathrm{pH}$, soil texture, and bulk density in Debre Dirhan Agricultural Research Center soil laboratory. We determined the soil bulk density by dividing the weight of oven-dried soil sample by the volume of core.

SOC is determined through laboratory analysis of the soil carbon concentration, volume of the soil sample, and the bulk density of soil samples collected in the study area (David 2013). The soil samples were dried in ovendry by $70{ }^{\circ} \mathrm{C}$ for SOC content (\%) and $105^{\circ} \mathrm{C}$ for bulk density until getting constant weight and analyzed (Negash and Starr 2015). Before that, the soil samples were treated with HCL acid to remove inorganic carbon. Then the soil organic carbon was determined following the wet digestion method (Walkley 1934), A correction factor of 1.33 was applied to account for the incomplete oxidation of 
organic carbon that is known to occur with the WalkleyBlack method (Rosell and Gasparoni 2000).

Soil organic carbon (SOC) was determined by using the equation (Subedi et al. 2010; Pearson et al. 2005); minimum to $1.38 \mathrm{~g} \mathrm{~cm}^{-3}$ maximum value with the average value of $1.21 \mathrm{~g} \mathrm{~cm}^{-3}$. Soil organic matter was range from $1.14-3.38 \%$. There was strong variation in soil organic carbon stock in parkland agroforestry practice

$$
\operatorname{SOC}(\mathrm{Mg} / \mathrm{ha})=\operatorname{BD}\left(\mathrm{g} / \mathrm{cm}^{3}\right) \times \text { depth }(\mathrm{cm}) \times \text { carbon } \% \times 10^{-1}
$$

Where: $\mathrm{BD}=$ bulk density and $10^{-1}$ is a unit factor $\left(10^{-9} \mathrm{mg} \mathrm{Mg}^{-1} \times 10^{8} \mathrm{~cm}^{2} \mathrm{ha}^{-1}\right)$.

$$
\mathrm{BD}\left(\mathrm{gm} / \mathrm{cm}^{3}\right)=(\text { oven }- \text { dryweight of the soil }) /(\text { volume of the core })
$$

\section{Results}

\section{Biomass carbon stocks in parkland agroforestry practice}

The species-specific allometric equations that used to estimate biomass of tree species are selected based on their developed agro ecology that relates with the study site (Appendix 2).

There was a variation in the mean above-ground carbon stock between the kebeles on PLAP in study areas (Appendix 2). PLAP in Bolo Slase kebele had higher AGC $(9.39 \mathrm{Mg} / \mathrm{ha}$.) by $64.64 \%$ as compared to Agirat $(3.32 \mathrm{Mg}$ $\mathrm{C} \mathrm{ha}^{-1}$ ). The mean AGC and BGC along kebele were significantly different $(\mathrm{F}=3.09, \mathrm{p}<0.05)$. The difference in variation in BGC is similar to AGC in study kebels. The carbons stock in below ground of PLAP was higher in Bolo Slase (3.6 Mg C ha-1) than Agirat (1.39 $\mathrm{MgC} \mathrm{ha}^{-1}$.) at 0.05 significance levels. The contribution of aboveground and below-ground biomass carbon stock for total biomass carbon stock in parkland agroforestry practice is $71.58 \%$ and $28.42 \%$, respectively. SOC, attitude, and $\mathrm{pH}(1: 2.5)$ are correlated with each other. Above-ground carbons stock in Acacia nilotica $(0.46 \mathrm{Mg} /$ tree), Acacia abyssinica $\left(0.215 \mathrm{Mg} \mathrm{C} \mathrm{ha}^{-1}\right)$ and Croton macrostachus $\left(0.193 \mathrm{Mg} \mathrm{C} \mathrm{ha}{ }^{-1}\right.$ ) were higher than other tree species in parkland agroforestry practice in study areas (Appendix 1). Acacia nilotica, Acacia abyssinica, and Croton macrostachus sequestered $2.12 \mathrm{Mg}, 0.98 \mathrm{Mg}$, and $0.88 \mathrm{Mg}$ $\mathrm{CO}_{2}$ respectively. There is strong variation in AGC, BGC and $\mathrm{CO}_{2}$ sequestration potential of tree in study areas $(\mathrm{F}=4.34, \mathrm{p}<0.01)$.

\section{Soil organic carbon stock}

Unlike AGC and BGC, Soil organic carbons were higher in korma Agree $\left(66.59 \mathrm{Mgha}^{-1}\right.$.) than Bolo Giorgis $\left(40.34 \mathrm{Mgha}^{-1}\right.$.). Similar to our hypothesis; the mean soil organic carbon along kebele was significant different $(\mathrm{F}=11.29, p<0.001)$. The average carbon stock of parkland agroforestry practice in soil organic carbon in the study area was $51.31 \mathrm{Mg} \mathrm{ha}^{-1}$. The bulk density of soil found in the study site was ranged from $1.01 \mathrm{~g} \mathrm{~cm}^{-3}$ of

\section{Total carbon stock of PLAP}

Total carbon stock of parkland agroforestry practice across kebele have statistically significant difference $(\mathrm{F}=7.74, P<0.001)$. Total carbon stock potential of parkland agroforestry practice in $\mathrm{M} /$ Shenkora on average was $59.65 \mathrm{Mg} \mathrm{C} \mathrm{ha}{ }^{-1}$. The highest total carbon stock density scores in korma Ager $\left(73.71 \mathrm{Mg} \mathrm{C} \mathrm{ha}{ }^{-1}\right)$ and the lowest in Bolo Giorgis $\left(48.87 \mathrm{Mg} \mathrm{C} \mathrm{ha}^{-1}\right)$. The contribution of AGC, BGC, and SOC for total carbon was 10.02, 3.98, and $86.08 \%$; respectively. Low altitude agro ecology has the higher carbon stock by $33.7 \%$ than mid altitude agroecology in the study area.

\section{Discussion \\ Biomass carbon stock of PLAP}

Biomass carbon stock of parkland agroforestry practice showed that there is significant variation along with different kebele of agro ecology; these are due to biomass affected by stand age, tree species and structure, managements, diversity and composition (Chave et al. 2004). Our result indicates that mean biomass and its carbon stock of PLAP was higher in mid altitude (B/Giorgis and B/Slase) agro-ecology than low altitude (Agirat and Korma Ager) agro-ecology. These are due to number of tree per hectare was higher in mid altitude agro ecology because of the presence of favorable environmental condition than low altitude agro-ecology so that; the presence of species characterized by large individuals and also possibly due to the favorable conditions for tree growth in the middle altitude, because few large individuals can account for a large amount of above and below ground carbon (Rahayu and Lusiana 2005). The biomass carbon stock is higher in high gradient elevation than low gradient elevation. This agrees with the results of Gebrewahid et al. 2018 that was carried out in Tigray, North Ethiopia. However, not agree with the result of (Leuschner et al. 2007; Zhu et al. 2010) who reported that above and below-ground tree biomass and its carbon stock decline with an increase in altitude. 
The present study show that, individual tree's biomass carbon stock range from 0.002 to $0.29 \mathrm{Mg} \mathrm{C}$. Carbon storage in individual tree species varies from $0.04 \mathrm{Mg} \mathrm{C}$ to $25.65 \mathrm{Mg} \mathrm{C}$ (Mishra et al. 2012). Tree species as they vary widely in properties that drive carbon sequestration such as growth, mortality, decomposition and their dependency on climate (Purves and Pacala 2008; Ramanathan and Feng 2008).

The mean total biomass carbon stock of PLAP in the study area was $8.34 \mathrm{Mg} \mathrm{C} / \mathrm{ha}$. The result was substantially higher than the parkland agroforestry system in Gununo Watershed, Wolayitta Zone, Ethiopia (Aklilu et el. 2015), However lower than that of the study of (Gebrewahid et al. 2018) that was carried out in Tigray, for traditional agro- forestry systems in the tropics reported $145 \mathrm{Mg} \mathrm{C}$ ha -1 (Kirby KR 2007) and (Montagnini and Nair 2004). This could be due to lower diameter trees documented in my study. The average above-ground carbon storage potential of agroforestry systems in semiarid, sub-humid, humid and temperate regions has been estimated to be 9, 21, 50 and $63 \mathrm{Mg} \mathrm{C} \mathrm{ha}{ }^{-1}$, respectively (Montagnini and Nair 2004). The total biomass carbon stock of PLAP in the study area was in the range of $0.98-26.89 \mathrm{Mg} \mathrm{C} / \mathrm{ha}$. Therefore, this result was within the range reported on a global scale Agroforestry system stores 12 to $228 \mathrm{Mg}$ C ha -1 (Dixon 1995). The trees on farmland frequently are managed by pollarding, thinning and coppicing every year at the end of the dry season to reduce its shading effect and competition for light and nutrition on the crop; that case to reduce tree biomass (Jandl et al. 2007).

\section{Soil organic carbon}

Soil organic carbon is a significant carbon pool because it has the longest residence time among organic carbon pools (Lugo and Brown 1993). Our results show that soil organic carbon had an inverse relationship with soil $\mathrm{pH}$ (Kundu et al. 2017) and elevation gradient (Appendix 2) (Mawer et al. 2018; Negash and Starr, 2015). At low soil $\mathrm{pH}$ the decomposition rate is reduce due to that there are high accumulation of SOC (Mcclaugherty 2007). Soil organic carbon of PLAP in the study area ranged between $29.66 \mathrm{Mg} \mathrm{C} \mathrm{ha}{ }^{-1}$ and $92.86 \mathrm{Mgha}^{-1}$. These results are in line with the range of $18.5-52.5 \mathrm{Mg} \mathrm{C} \mathrm{ha}^{-1}$ and 22.4$54.0 \mathrm{Mg} \mathrm{C} \mathrm{ha}{ }^{-1}$ that reported in stocks of cultivated and grazing land of East and West Africa (Brown et al. 2012) and that of parkland agroforestry practiced in southern Ethiopia was ranges in $28.2-98.9 \mathrm{Mgha}^{-1}$ ( Demessie et al. 2013). The result shows that, SOC is higher in low land agro ecology than midland agro ecology due to SOC has an inverse relationship with elevation gradient (Mawer et al. 2018; Negash and Starr 2015; Aklilu et al. 2015). The increasing tendency of carbon density with decreasing altitude may be because of soil leaching, better mineralization and stabilization of SOC at lower altitudes (Mawer et al. 2018). The range of SOC that in the study that was carried out in Tigray, was 2.28 and $40.5 \mathrm{Mg} \mathrm{C} \mathrm{ha}^{-1}$ (Gebrewahid et al. 2018). The mean soil organic carbon of PLAP in the study area was $51.31 \mathrm{Mg}$ $\mathrm{C} \mathrm{ha}{ }^{-1}$. SOC in our study was remarkably high as compared to results conducted in semi-arid Acacia etabica woodland in southern Ethiopia $\left(43 \mathrm{Mgha}^{-1}\right.$ ) (Lemenih, 2004), carried out in Tigray (20.07 $\mathrm{Mg} \mathrm{C} \mathrm{ha}^{-1}$ ) (Gebrewahid et al. 2018), in the wolayitta zone (49.05 $\left.\mathrm{Mgha}^{-1}\right)$ ( Aklilu et al., 2015) and agroforestry systems in Central India (27 $\mathrm{Mgha}^{-1}$ ) (Swamy and Puri 2005). However, the SOC in our study remarkably lower as compared to results that conducts in Cheha woreda, Gurage zone for cultivated land (73 Mg C ha ${ }^{-1}$.) (Semere 2017). As (Lal 2004) report the soil organic carbon stock for the tropical forest, tropical savannah, and tropical agricultural land was $121-123 \mathrm{Mg} \mathrm{C} \mathrm{ha}^{-1}, 110-117 \mathrm{Mg} \mathrm{C} \mathrm{ha}^{-1}$, and $80-103 \mathrm{Mg} \mathrm{C}^{-1}$ respectively.

Soil organic carbon stock studied in different agro ecology has a significant difference. These are due to the composition, land-use history, management and structure of vegetation along the agro-ecology zone, which may accumulate the different amount of organic matter due to high inputs from root biomass and above-ground (Laganière et al. 2010; Jose 2009 ; Sauer et al. 2007). Diversified tree species have high fine root production due to that the SOC is high. Thinning and pruning of trees may reduce SOC sequestration by reducing litter fall and accelerating decomposition due to changes in understory light, air/ soil temperature, and soil moisture regimes (Lorenz and Lal 2014).

\section{Total carbon stock of PLAP}

The distribution of carbon stocks between biomass and soil differed among agro ecology and varied among kebeles. The mean total carbon stock of PLAP in the studied area was $59.65 \mathrm{Mg} \mathrm{C} / \mathrm{ha}$. This is higher than total carbon stock of parkland agroforestry practice in the wolayitta zone (51 Mg C ha-1) (Aklilu et al., 2015), carried out in Tigray (31 Mg C ha-1) (Gebrewahid et al. 2018), and $46 \mathrm{Mg} \mathrm{C} \mathrm{ha}{ }^{-1}$ in the Sahel (Luedeling and Neufeldt 2012). The total carbon stock of the study area is in the range of $36.24 \mathrm{Mg} \mathrm{C} \mathrm{ha}^{-1}-94.08 \mathrm{Mg} \mathrm{C} \mathrm{ha}^{-1}$. The average total carbon stock of PLAP was within range of tropical agroforestry $7.9-105 \mathrm{Mg} \mathrm{C} \mathrm{ha}{ }^{-1}$ (Montagnini and Nair 2004), Cocoa-based agroforestry practiced in Nigeria that ranged $16-96.01 \mathrm{Mg} \mathrm{C} \mathrm{ha}^{-1}$ (Oke and Olatiilu 2011) and traditional agroforestry system of humid subtropical ranges $10.29-31.86 \mathrm{Mg} \mathrm{C} \mathrm{ha}^{-1}$ (Yadava 2010).

The difference of total carbon stock of the practice in the study areas between kebeles arise from difference in farm size, socio-economic needs, species diversity, the 
age of trees, local climate, number of tree coverage, and tree spacing among agroforestry system (Kumar 2011) and higher levels of disturbance (pruning and damage), intensive management practices, and small land size that forces scattered trees on farmland not only having a higher density of woody perennials but also an accumulation of other plants and crops per unit area.

\section{Conclusions}

The parkland agroforestry practice in the woreda has stores $59.65 \mathrm{Mg} \mathrm{C}$ ha -1 . However, this carbon sequestration potential of the practice varied among sites (i.e., among each kebele), which is due to differences in vegetation structure, the density of trees per hectare and management practice. In spite of the aforementioned ecosystem services of the practice, the parkland agroforestry practice of Minjar Shenkora woreda has faced some challenges like: cutting of trees by theft due to high demand for tree products, change of plowing and harvesting techniques such as use of tractors and machine harvesters and free grazing that threatened its long existence. Hence, this calls for an integrated action in all levels to control the problem and avoid the damage on the trees and the growth of naturally regenerated seedlings that are important to sustain the practice. The practice should be conserving and promote by climate change program to sustain the practice and improve carbon storage potential of the practice. The governments should give attention for agroforestry practice because of its role for climate change mitigation.

\footnotetext{
Abbreviations

AFS: Agroforestry system; AGB: Above ground biomass; AGC: Above ground carbon; AGCO2: Above ground carbon dioxide; BGB: Below ground biomass; BGC: Below ground carbon; BGCO2: Below ground carbon dioxide; C: Carbon; CO2: Carbon dioxide; Cof:: Correlation coefficient; CO2e: Carbon dioxide equivalent; DBH: Diameterat Brest height; DSH: Diameter at stump height; GHG: Greenhouse gases; GPS: Global positioning system; HCL: Hydrochloric acid; IPCC: Inter-governmental Panel on Climate Change; MSDARDO: Minjar
}

Shenkora woreda Agriculture and Rural development office; MSCO: Minjar Shenkora WoredaCommunication office; PLAP: Parkland agroforestrypractice; SOC: Soil organic carbon; WBISPP: Wood Biomass Inventory and Strategic Planning Project; WMO: World metrological organization.

\section{Acknowledgements}

A number of individuals and institutions have contributed to this work and it is impossible for me to mention all by name. I thank all of them. Foremost, my special thanks go to my respected advisors Seid muhei (Dr.), and Solomon Mull for their valuable comments and constructive criticisms which have greatly improved this work. I would also like to thank Wollo university and Debre Birhan Agriculture research center for providing this study opportunity and paying my salary during my stay in college. I also want to thank the Debre Birhan Agricultural Research Centre for their provision of vehicles and drivers during the reconnaissance survey at Minjar shenkora. Last but not least; I want to express my everlasting gratitude to my family and friends who always inspire me to build my educational career.

\section{Authors' contribution}

RET designed and conducted the experiments at field, data collection, analysis, interpret the results and finally prepared the draft manuscript. SM and SM Designed the experiments, interpret the results, review the full manuscript and improve the contents of these manuscripts. All authors read and approved the final manuscript.

\section{Funding}

I thank Amhara Regional Agriculture Research Institute; Debre Birhan Agriculture Research Center for support these experiments by provide budget, vehicles and drivers during the reconnaissance survey and data collection at Minjar shenkora

\section{Availability of data and materials}

The datasets used and/or analyzed during the current study are available from the corresponding author on reasonable request.

\section{Ethics approval and consent to participate}

Not applicable.

\section{Consent for publication}

Not applicable.

Competing interests

The authors declare that they have no competing interests in this section.

\section{Author details}

${ }^{1}$ Debre Birhan Agriculture Research Center, Amhara Region Agriculture Research Institute, P.O. Box 112, Debre Berhan, Ethiopia. ${ }^{2}$ Wollo University, Dessie, Ethiopia.

\section{Appendices \\ Appendix 1}

See Figs. 1, 2, 3 


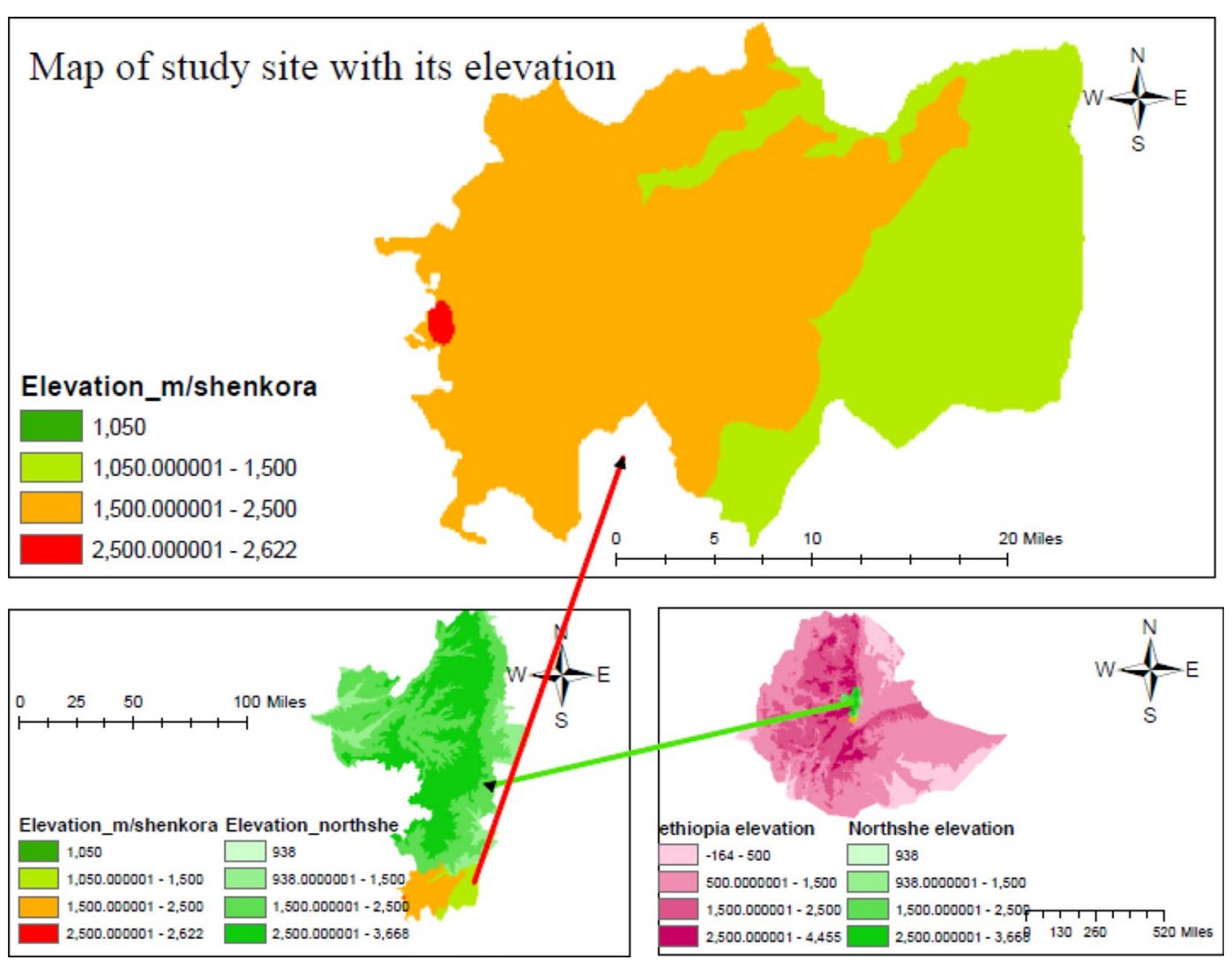

Fig. 1 Location map of Minjar Shenkora wored

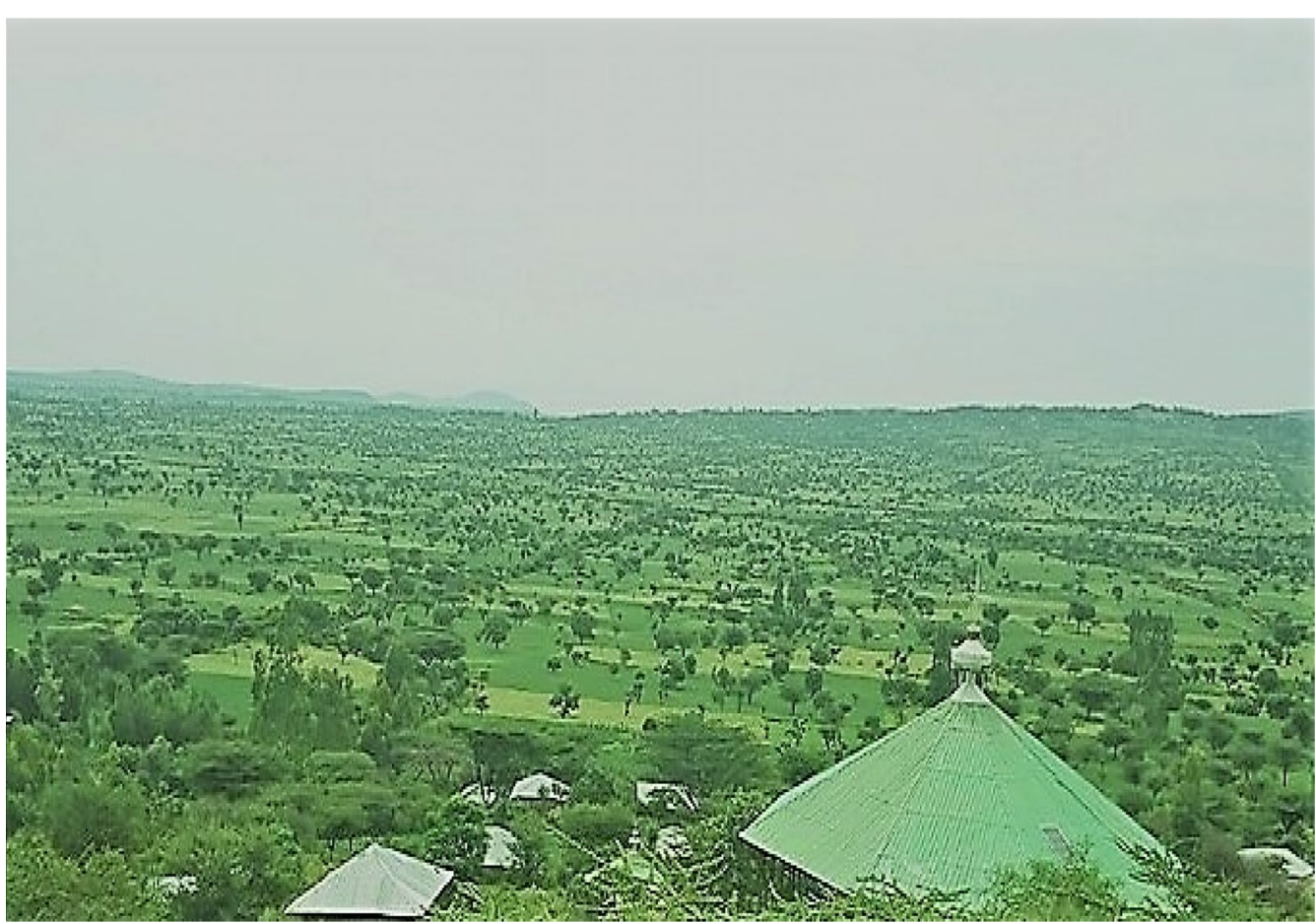

Fig. 2 Photo of the study area 


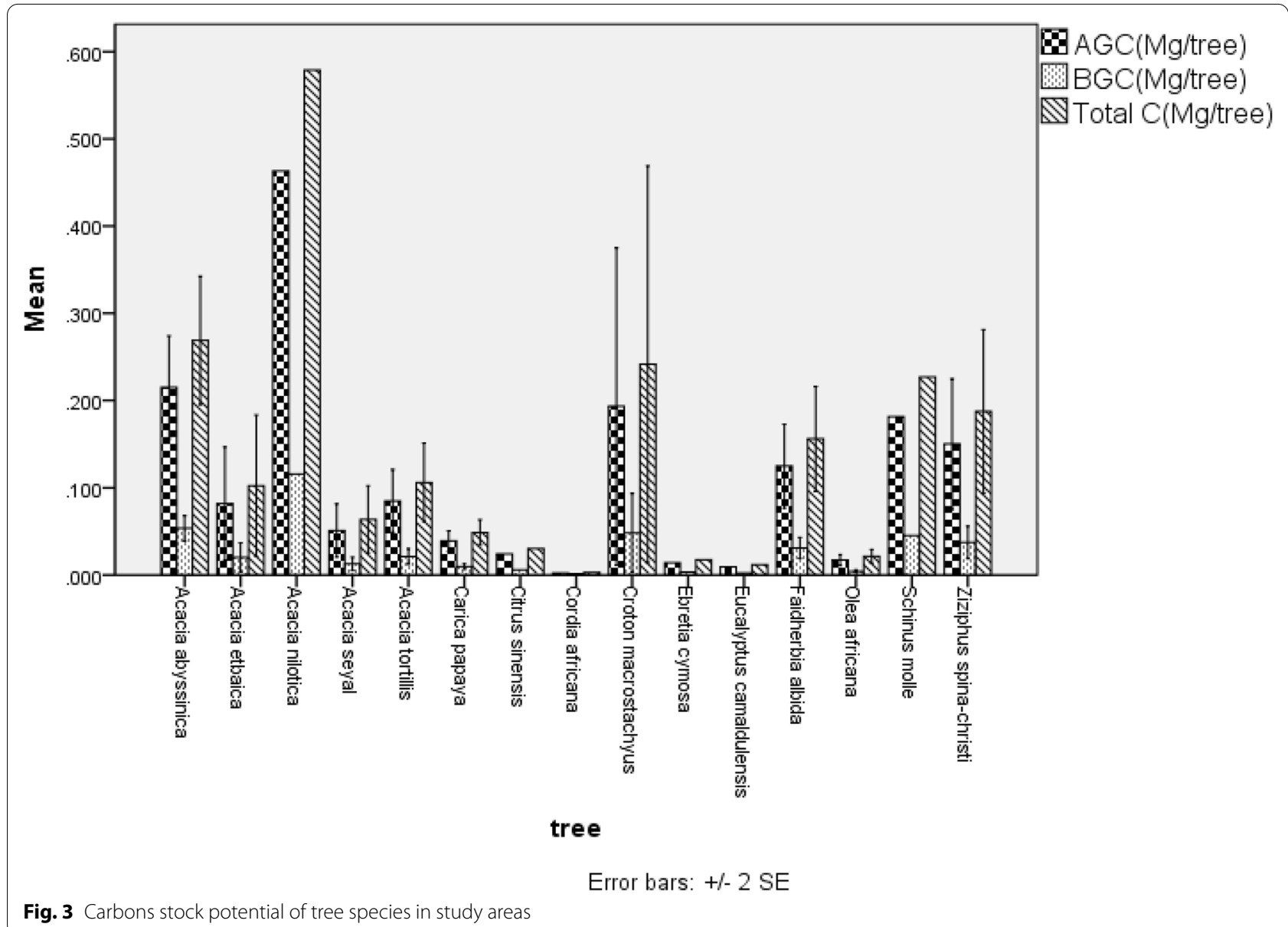

\section{Appendix 2}

See Tables 1, 2 and 3

Table 1 The species and their allometric equations were applied in the study area

\begin{tabular}{|c|c|c|c|}
\hline Species & Allometric equation used & $\mathrm{R}^{2}$ & References \\
\hline Acacia seyal & $A G B=\left(0.9103^{*} D S H\right)+\left(0.6782^{*}(D S H \exp 1.7)\right)$ & 0.9 & (WBISPP 2004) \\
\hline Acacia abyssinica & $\mathrm{AGB}=\left(0.0497^{*} \mathrm{DSH}\right)+\left(0.0300^{*}(\mathrm{DSH} \exp 2.8)\right)$ & 0.9 & (WBISPP 2004) \\
\hline Acacia etbaica & $A G B=\left(-0.1024^{*} D S H\right)+\left(0.1502^{*}(D S H \exp 2.3)\right)$ & 0.88 & (WBISPP 2004) \\
\hline Acacia nilotica & $\mathrm{AGB}=\left(2.3624^{*} \mathrm{DSH}\right)+\left(0.0035^{*}(\mathrm{DSH} \exp 3.4)\right)$ & 0.96 & (WBISPP 2004) \\
\hline Acacia tortillis & $A G B=\left(0.1725^{*} D S H\right)+\left(0.0106^{*}(D S H \exp 3.0)\right)$ & 0.97 & (WBISPP 2004) \\
\hline Carica papaya & $\begin{array}{l}A G B=\left(0.02445^{*} D S H\right)+\left(0.2451^{*}(D S H \exp 2.6)\right)+(- \\
\left.0.1022^{*}(D S H \exp 2.8)\right)\end{array}$ & 0.92 & (Kuyah et al. 2012) \\
\hline Croton macrostachyus & $A G B=\left(0.3679^{*} D S H\right)+\left(0.0459^{*}(D S H \exp 2.5)\right)$ & 0.99 & (WBISPP 2004) \\
\hline Ebretia cymosa & $A G B=\left(0.8808^{*} D S H\right)+\left(0.0348^{*}(D S H \exp 2.5)\right)$ & 0.98 & (Larwanou M. 2010) \\
\hline Faidherbia albida & $A G B=7.985 \mathrm{Dbh}+32.277$ & 0.33 & (Larwanou M. 2010) \\
\hline Olea africana & $A G B=\left(0.6806^{*} D S H\right)+\left(0.0422^{*}(D S H \exp 2.7)\right)$ & 0.91 & (WBISPP 2004) \\
\hline Ziziphus spina-christi & $A G B=\left(0.0340^{*} D S H\right)+\left(0.0431^{*}(D S H \exp 2.6)\right)$ & 0.97 & (WBISPP 2004) \\
\hline Eucalyptus camaldulensis & $A G B=0.0155(D B H)^{2.5823}$ & 0.99 & (Hailu 2002) \\
\hline
\end{tabular}


Table 2 Pearson correlation among the studied characters

\begin{tabular}{|c|c|c|c|c|c|}
\hline & $\begin{array}{l}\text { AGB } \\
\left(\mathrm{MgCha}^{-1}\right)\end{array}$ & $\begin{array}{l}\mathrm{SOC}(0-40 \mathrm{~cm}) \mathrm{Mg} \mathrm{C} \\
\mathrm{ha}^{-1}\end{array}$ & Number of trees/ha & $\mathrm{pH}(1: 2.5)$ & Altitude (M) \\
\hline $\mathrm{AGBC}(\mathrm{MgCha}-1)$ & 1 & -0.220 & -0.101 & 0.086 & 0.134 \\
\hline $\mathrm{SOC}(0-40 \mathrm{~cm}) \mathrm{Mg} \mathrm{C} \mathrm{ha}{ }^{1}$ & -0.220 & 1 & -0.046 & -0.139 & $-0.638^{* *}$ \\
\hline No.of trees/ha & -0.101 & -0.046 & 1 & $0.512^{* *}$ & 0.332 \\
\hline $\mathrm{pH}(1: 2.5)$ & 0.086 & -0.139 & $0.512^{* *}$ & 1 & $0.509^{* *}$ \\
\hline Altitude (M) & 0.134 & $-0.638^{* *}$ & 0.332 & $0.509^{* *}$ & 1 \\
\hline
\end{tabular}

${ }^{* *}$ Correlation is significant at the 0.01 level (2-tailed)

Table 3 Mean ( \pm standard error) biomass $\left(\mathrm{Mg} \mathrm{ha}^{-1}\right)$, biomass carbon, SOC and total carbon stocks ( $\left.\mathrm{Mg} \mathrm{C} \mathrm{ha}^{-1}\right)$ for each of the kebele and results of one-way ANOVA (at $a=0.05$ )

\begin{tabular}{|c|c|c|c|c|c|c|}
\hline \multirow[t]{2}{*}{ Biomass and carbon pool } & \multicolumn{4}{|l|}{ Kebeles } & \multirow[b]{2}{*}{ GM. } & \multirow[b]{2}{*}{ Sig } \\
\hline & B/giorgis (M.altitude) & B/slasi (M.altitude.) & Agirat (L.altitude) & Korma ager (L.altitude) & & \\
\hline $\mathrm{AGB}\left(\mathrm{Mg} \mathrm{ha}^{-1}\right)$ & $12.71(2.88)^{a, b}$ & $19.54(4.81)^{\mathrm{a}}$ & $6.92(1.35)^{\mathrm{b}}$ & $10.56(1.77)^{a, b}$ & 12.44 & $*$ \\
\hline BGB $\left(\mathrm{Mg} \mathrm{ha}^{-1}\right)$ & $5.07(1.05)^{\mathrm{ab}}$ & $7.50(1.72)^{\mathrm{a}}$ & $2.89(0.53)^{b}$ & $4.28(0.68)^{a, b}$ & 4.94 & * \\
\hline AGC $\left(\mathrm{Mg} \mathrm{ha}^{-1}\right)$ & $6.1(1.38)^{\mathrm{ab}}$ & $9.38(2.31)^{\mathrm{a}}$ & $3.32(0.65)^{b}$ & $5.07(0.85)^{a, b}$ & 5.97 & * \\
\hline $\mathrm{BGC}\left(\mathrm{Mg} \mathrm{ha}^{-1}\right)$ & $2.43(0.5)^{\mathrm{ab}}$ & $3.6(0.83)^{\mathrm{a}}$ & $1.39(0.25)^{b}$ & $2.05(0.33)^{a, b}$ & 2.37 & * \\
\hline SOC Mg ha-1 $0-20 \mathrm{~cm}$ & $20.85(1.42)^{b}$ & $23.84(1.18)^{b}$ & $26.55(1.64)^{a, b}$ & $33.14(2.65)^{\mathrm{a}}$ & 26.09 & $* * *$ \\
\hline SOC Mg ha-1.21-40 cm & $19.49(1.09)^{b}$ & $21.38(2.38)^{b}$ & $26.55(1.71)^{\mathrm{ab}}$ & $33.45(2.22)^{\mathrm{a}}$ & 25.22 & $* * *$ \\
\hline sOC Mg ha ${ }^{-1} \cdot 0-40 \mathrm{~cm}$ & $40.34(1.84)^{b}$ & $45.22(3.36)^{b}$ & $53.10(3.25)^{\mathrm{b}}$ & $66.59(4.62)^{\mathrm{a}}$ & 51.31 & $* * *$ \\
\hline $\mathrm{TC}\left(\mathrm{Mg} \mathrm{ha}^{-1}\right)$ & $48.87(2.53)^{b}$ & $58.2(4.56)^{b}$ & $57.81(3.18)^{b}$ & $73.71(2.27)^{\mathrm{a}}$ & 59.65 & $* * *$ \\
\hline
\end{tabular}

Similar letter shows no a significant difference and different letters indicate a significant difference between groups at $5 \%$ level significant. ${ }^{*} p<0.05,{ }^{* * *} p<0.001$. Where; M.altitude weynadega agro-ecology, L.altitude lowland agro-ecology. TCTotal carbon, GM grand mean and Sig. significance

Received: 5 October 2020 Accepted: 14 December 2020

Published online: 08 January 2021

\section{References}

Abdelkadir A, Bishaw B (2003) Agroforestry and community forestry for rehabilitation of degraded watersheds in the Ethiopian Highlands. Intern Symp Contemporary Devel Iss Ethiopia 78:52-75

Asako T (2007) Carbon sequestration potential of agroforestry systems in the west African Sahel: An assessment of biological and socio-economic feasibility. Doctoral diss Department of Forest Resources and Conservation University of Florida pp 15-16

Asefa A, Worku G (2014) Woody plant inventory and diversity in traditional agroforestry of selected peasant association of south Gonder Zone\&nbsp;north west Ethiopia. J Environ Earth Sci 4(15):8-17

Bajigo A, Tadesse M, Moges Y, Anjulo A (2015) Ecosystem \& ecography estimation of carbon stored in agroforestry practices in Gununo. Ecosyst Ecogr 5(1):1-5. https://doi.org/10.4172/2157-7625.1000157

Bayala J, Balesdent J, Marol C, Zapata F, Teklehaimanot Z et al (2006) Relative contribution of tree and crops to soil carbon content in a parkland system in Burkina Faso variations in natural 13C abundance. Nutr Cycl Agroecosyst 76:161-169

Brown S, Grais A, Ambagis S, Pearson T (2012) Baseline GHG emissions from the agricultural sector and mitigation potential in countries of East and West Africa. CCAFS Working paper, (13)

Chave J, Condit R, Aguilar S, Hernandez A, Lao S, Perez R (2004) Error propagation and scaling for tropical forest biomass estimates. Philos Trans R Soc Lond B Biol Sci 359:409-420

David S (2013) Field data collection for landscape carbon inventories. Carbon benefits project: modelling, measurement and monitoring, Nairobi
Demessie A, Singh BR, Lal R (2013) Soil carbon and nitrogen stocks under chronosequence of farm and traditional agroforestry land uses in Gambo District, southern Ethiopia. Nutr Cycl Agroecosyst 95(3):365-375

Dixon R (1995) Agroforestry systems: sources of sinks of greenhouse gases? Agrofor Syst 31(2):99-116. https://doi.org/10.1007/BF00711719

Friis I, Demissew S, Van Breugel P (2010) Atlas of the potential vegetation of Ethiopia. Det Kongelige Danske Videnskabernes Selskab

Gebrewahid Y, Teka K, Birhane E (2018) Carbon stock potential of scattered trees on farmland along an altitudinal gradient in Tigray, Northern Ethiopia. Ecol Process 7(40):2-8

Hailu Z (2002) Ecological impact evaluation of Eucalyptus plantations in comparison with agricultural and grazing land-use types in the highlands of Ethiopia

Israel GD (1992) Determining sample size, Florida cooperative extention service. University of Florida PEOD-6, Florida

Jandl $R$ et al (2007) Carbon sequestration and forest management. CAB Reviews 2(017):1-16. https://doi.org/10.1079/PAVSNNR20072017

Jose S (2009) Agroforestry for ecosystem services and environmental benefits: an overview. Agrofor Sys 76:1-10

Jose S (2012) Agroforestry for biomass production and carbon sequestration: an overview. Agroforest Syst 86:105-111. https://doi.org/10.1007/ s10457-012-9573-x

Kirby KR, Potvin C (2007) Variation in carbon storage among tree species: implications for the management of a small-scale carbon sink project. For Ecol Manag 246(2-3):208-221. https://doi.org/10.1016/j.forec 0.2007 .03 .072

Kumar BM (2011) Species richness and aboveground carbon stocks in the homegardens of central Kerala, India. Agric Ecosyst Environ 140(3-4):430-440 
Kumar BM, Nair PR (eds) (2011) Carbon sequestration potential of agroforestry systems: opportunities and challenges, vol 8. Springer, Netherlands

Kundu MC et al (2017) Effect of different land uses on soil organic carbon in new alluvial belt of West Bengal. Int J Bio-res Env Agril Sci 3(2):517-520

Kuyah S, Dietz J, Catherine M, Jamnadassa R, Mwangi P, Coe R, Neufeldt H (2012) Allometric equations for estimating biomass in agricultural landscapes: aboveground biomass. Agric Ecosyst Environ 158:216-224

Laganière J, Angers D, P. D (2010) Carbon accumulation in agricul tural soils after afforestation: a meta-analysis. Glob Chang Biol 16:439-453. doi:https ://doi.org/10.1111/j.1365-2486.2009.01930.x

Lal R (2004) Soil carbon sequestration to mitigate climate change. Geoderma 123(1-2):1-22. https://doi.org/10.1016/j.geoderma.2004.01.032.

Lal R (2005) Forest soils and carbon sequestration. For Ecol Manage 220:242258. https://doi.org/10.1016/j.foreco.2005.08.015

Larwanou M, Yemshaw Y, Saadou M (2010) Prediction models for estimating foliar and fruit dry biomasses of five Savannah tree species in the West African Sahel. Int J Biol Chem Sci 4(6):2245-2256

Lasco RD, Delfino RJP, Espaldon MLO (2014) Agroforestry systems: helping smallholders adapt to climate risks while mitigating climate change. WIREs Clim Change 5(December):825-833. https://doi.org/10.1002/ wCC.301

Lemenih M (2004) Soil carbon stocks and turnovers in various vegetation types and arable lands along an elevation gradient in southern Ethiopia. Geoderma 123:177-188

Leuschner C, Moser G, Bertsch C, Röderstein M, Hertel D (2007) Large altitudinal increase in tree root shoot ratio in tropical mountain forests of Ecuador. Basic Appl Ecol 8(3):219-230. https://doi.org/10.1016/jbaae 2006.02.004

Mishra AK, Singh J, Kumar V, Srivastava R, Srivastava S (2012) Standing carbon stock estimation in different tree species grown in dry tropical forests of vindhyan highland, Mirzapur, India

Lorenz K, Lal R (2014) Soil organic carbon sequestration in agroforestry systems. A review. Agron Sustain Dev. https://doi.org/10.1007/s1359 3-014-0212-y

Luedeling E, Neufeldt H (2012) Carbon sequestration potential of parkland agroforestry in the Sahel. Clim Change. https://doi.org/10.1007/s1058 4-012-0438-0

Lugo AE, Brown S (1993) Management of tropical soils as sinks or sources of atmospheric carbon. Plant Soil 149:27-41

Mawer $\mathrm{H}$ et al (2018) Effect of altitude and aspect on soil organic carbon and nitrogen stocks in the Catena Himalayan Mawer Forest Range. Catena. 158:63-68. https://doi.org/10.1016/j.catena.2017.06.017

Mcclaugherty C (2007) Plant litter decomposition, humus formation, carbon sequestration. Verlag, Berlin

Montagnini F, Nair PKR (2004) Carbon sequestration: an under environmental benefits of agroforestry systems. Agrofor Syst 61:281-295

Motuma T, Zebene A, Mulugeta L, E. K (2008) 'Woody species diversity in a changing landscape in the south-central highlands of Ethiopia'. Agriculture Ecosystems Environment 128:52-58

MSDARDO (2008) Minjar Shenkora District Agriculture and Rural development office. Annual work report (Unpublished). Arerty

Nair PKR et al (2010) Chapter five - carbon sequestration in agroforestry systems. Adv Agron 108:237-307

Nair PKR (2011) Carbon sequestration studies in agroforestry systems : a reality-check. Agroforest Syst. https://doi.org/10.1007/s10457-011-9434-z

Nair PKR, Gordon AM, Mosquera-Losada M-R (2008) Agro- forestry. In: Jorgensen SE, Fath BD (eds) Ecological Engineering, Encyclopedia of Ecology. Elsevier, Oxford, pp 101-110

Nair PKR, Kumar BM, Nair VD (2009) Agroforestry as a strategy for carbon sequestration. J Plant Nutr Soil Sci 172:10-23. https://doi.org/10.1002/ jpln.200800030

Negash MN (2013) The indigenous agroforestry systems of the south-eastern Rift Valley escarpment, Ethiopia: their biodiversity, carbon stocks, and litterfall

Negash M, Starr M (2015) Biomass and soil carbon stocks of indigenous agroforestry systems on the south-eastern Rift Valley escarpment Ethiopia. Plant Soil. https://doi.org/10.1007/s11104-015-2469-6
Nikiema A (2005) Agroforestry parkland species diversity: uses and management in semi-arid West-Africa (Burkina Faso)

Oke D, Olatiilu A (2011) Carbon storage in agroecosystems: a case study of the cocoa based agroforestry in Ogbese Forest reserve, Ekiti state, Nigeria. J Environ Prot 02(08):1069-1075. https://doi.org/10.4236/jep.2011.28123'

Pan Y, Birdsey RA, Fang J, Houghton R, Kauppi PE, Kurz WA, Phillips OL, Shvidenko A, Lewis SL, Canadell JG, Ciais P, Jackson RB, Pacala S, McGuire AD, Piao S, Rautiainen A, Sitch S (2011) Alarge and persistent carbon sink in the world's forests. Science 333:988-993. https://doi.org/10.1126/scien ce.1201609

Pearson T, Walker S, Brown S (2005) Sourcebook for land-use, land-use change and forestry projects. Winrock International and the Bio-carbon fund of the World Bank, Arlington

Purves D, Pacala S (2008) Predictive models of forest dynamics. Science 320:1452-1453

Rahayu S, Lusiana B (2005) Above ground carbon stock assessment for various land use systems in Nunukan, East Kalimantan. Carbon Stock Monitoring in Nunukan, East Kalimantan: a spatial and modelling approach. World Agroforestry Centre SE Asia, Bogor, pp 21-34

Ramanathan V, Feng Y (2008) On avoiding dangerous anthropogenic interference with the climate system: formidable challenges ahead. Proc Natl Acad Sci USA 105:14245-14250

Rosell RA, Gasparoni JC (2000) 'Soil organic matter evaluation. In: Lal R, Kimble JM, Follett RF, Stewart BA (eds) Assessment methods for soil carbon'. CRC/ Lewis Publishers, Boca Raton, pp 311-322

Sauer JT, Cambardella AC, Brandle RJ (2007) Soil carbon and tree litter dynamics in red cedar-scotch pine shelterbelt. Agrofor Syst 71:163-174

Semere NM (2017) Assessments of biomass and soil carbon stocks of agroforestry systems and adjacent cultivatedland, in Cheha District, Gurage Zone, Ethiopia. Hawassa University; Wondo Genet College of Forestry and Natural Resources

Subedi BP, Shiva SP, Ajay P, Eak R, Sanjeeb B, Tibendra RB, Shambhu C, Rijan $\mathrm{T}$ (2010) Forest carbon measurement: guidelines for measuring carbon stock in community managed forest. Funded by Norwegian Agency for Development

Swamy SL, Puri S (2005) Biomass production and Csequestration of Gmelinaarborea in plantation and agroforestry system in India. Agroforest Syst 64:181-195

Tadesse W (2015) GHG emission assessment guideline: aboveground biomass field guide for baseline Survey Federal Democratic Republic of Ministry of Agriculture. Addis Ababa

Talemos Seta and Sebsebe Demissew (2017) Diversity and standing carbon stocks of Agroforestry trees in Wenago District, Ethiopia. Int J Agrofor Silviculture 4(1):246-256

Walkley AB (1934) An examination of the Degtjareff methods for determining soil organic matter, and a proposed modification of the chromic acid titration method. Soil Sci 37(23):29-38

WBISPP (2004) A strategic plan for the sustainable development, conservation and management of the woody biomass resources: Final report. Federal Democratic Republic of Ethiopia, Ministry of Agriculture, Ethiopia, p 60

WMO Greenhouse gas bulletin (2007) Atmospheric carbon dioxide levels highest on record. World Meteorological Organization, Geneva

World Agroforestry Centre (ICRAF) (2006) Agroforestry for improved livelihoods and Natural resources conservation. An Agroforestry Policy Brief. World Agroforestry Centre (ICRAF), Nairobi

Yadava AK (2010) Carbon sequestration: underexploited environmental benefits of Tarai agroforestry systems. Indian J Soil Conserv 38(2):125-31

Zhu B, Wang X, Fang J, Piao S, Shen H, Zhao S (2010) Altitudinal changes in carbon storage of temperate forests on Mt Changbai, Northeast China. J Plant Res 123(4):439-452. https://doi.org/10.1007/s10265-009-0301-1

\section{Publisher's Note}

Springer Nature remains neutral with regard to jurisdictional claims in published maps and institutional affiliations. 